\title{
SYLVIE PATRON
}

\section{The Death of the Narrator and the Interpretation of the Novel}

\author{
The Example of Pedro Páramo by Juan Rulfo ${ }^{1}$
}

The death of the narrator is the death of the novel. (Kayser 1955, 34)

This article is an extension of my book on the problem of the narrator in fictional narrative (see Patron 2009). The narrator (the answer to the question "who speaks? «) is a concept used widely in the teaching of literature, even though it is a subject of continued debate within narrative theory or theories. Is there always a narrator in fictional narrative, or only in some narratives (which would presuppose that it is possible to call some narratives snarratorless)? The question divides scommunicationals theories of narrative ${ }^{2}$, according to which communication between a real or fictional narrator and a narratee is constitutive of the definition of narrative, from snon-communicational theories,${ }^{3}$ also termed spoetic theories of fictional narrative, ${ }^{4}$ which consider that fictional narrative, or a certain type of fictional narrative, and communication are mutually exclusive categories. According to these theories, fictional narrative is not, or is not always, an act of communica-

${ }^{1}$ A French version of this article is forthcoming in: Sylvie Patron (ed.), Théorie, Analyse, Interprétation des Récits / Theory, Analysis, Interpretation of Narratives, Berne 2011. It is followed by a "Note sur la traduction des temps verbaux dans Pedro Páramo«, which essentially deals with the choice between the passé simple and the passé composé in French translations of Juan Rulfo's novel.

2 The term was coined by S.-Y. Kuroda (see notably Kuroda 1976, 107 et passim). It originally applied to the theories developed by Roland Barthes, Tzvetan Todorov and Gérard Genette, but can be extended to all classical and post-classical narratologies.

3 The term is a logical consequence of Kuroda's propositions (see Kuroda 1976, notably 114, 123); however, it does not figure as such in Kuroda's work. It has several drawbacks, not the least of which being that it presents communicational theories and non-communicational theories as if they were opposed to each other, whereas their relation is rather more one of inclusion (non-communicational theories are really theories of optional fictional communication).

${ }^{4}$ The term was coined by Kuroda (see Kuroda 1976, 130, 140; Kuroda 1979, 11; Kuroda 1980, 79). It follows from certain propositions in Käte Hamburger (see Hamburger 1993, 10 - 13; Kuroda 1976, $124-125$ ). It was adopted by Ann Banfield (see Banfield 1979, 20 ; Banfield 2003, 479). Among the representatives of non-communicational or poetic theories of narrative, Mary Galbraith could also be mentioned (see Galbraith 1995) as well as other contributors to the same volume (edited by Duchan/Bruder/Hewitt 1995). 
tion. To the question "who speaks? «, they reply that, in certain fictional narratives, nobody speaks - or more precisely, the question is not asked since it is not pertinent. These theories also aim to rehabilitate the function of the author as creator of the fictional narrative.

In this article, I intend to put communicational theories of narrative and noncommunicational or poetic theories of fictional narrative to the test of an empirical close reading, with the aim of evaluating not only their internal consistency, but also their heuristic value and their pertinence to the interpretation. To do so I have chosen Juan Rulfo's novel Pedro Páramo (1955, English translation 1959, new translation 1994). ${ }^{5}$

\section{Pedro Páramo: A Complex Fictional Montage}

Pedro Páramo is made up of sixty-nine fragments of unequal length which are neither numbered nor given titles, but rather separated by typographical spaces. ${ }^{6}$ Instead of being organised in a unitary fashion around a storyline, the novel links several stories, the first of which is developed and continued from one fragment to the next (this is the story of Juan Preciado, Pedro Páramo's legitimate son, from the death of his mother in Sayula, to his own death in the village of Comala), while others are developed but fragmentary (this is the case notably of the story of Pedro Páramo, from his childhood in Comala to his death at his property, La Media Luna), and still others are not developed, and are more embryonic than fragmentary (this is the case, for example, of the history of Dorotea, mentioned in fragment 36). From the point of view of narrative modes, two main parts of the novel can be distinguished. The first, from fragment 1 to fragment 35, is dominated by Juan Preciado's narrative recounting his journey from Sayula to Comala, after his mother's death, his arrival in Comala and his encounter with the ghosts of its inhabitants (which he at first takes to be its rreal inhabitants), and finally his own death on the town square of Comala (Juan Preciado's narrative might in fact be termed a "text after death", Doležel 1998, 159). These are the opening lines of the first fragment:

Vine a Comala, porque me dijeron que acá vivía mi padre, un tal Pedro Páramo. Mi madre me lo dijo. Y yo le prometí que vendría a verlo en cuanto ella muriera. Le apretésus manos en señal de que lo haria, pues ella estaba por morirse y yo en un plan de prometerlo todo.

(Rulfo 2007, 65)

5 The 1959 text was translated by Lysander Kemp, the 1994 text by Margaret Sayers Peden (hereafter Rulfo 1994).

${ }^{6}$ In the wake of numerous other commentators, I shall call the units separated by typographical blank spaces 'fragments`, reserving the term ssequences ‘ for the series of fragments, whether continuous or discontinuous, which correspond to the same unit of narrative content. Certain commentators use the term sequences ( ssecuencias) for the units I am terming sfragments`. I will use consecutive numbering henceforth. 
I came to Comala because I had been told that my father, a man named Pedro Páramo, lived there. It was my mother who told me. And I had promised her that after she died I would go see him. I squeezed her hands as a sign I would do it. She was near death, and I would have promised her anything.

(Rulfo 1994, 3)

It is clear that this passage refers to an enunciative or narrative situation located in Comala ("Vine a Comala", "acá", "que vendría a verlo"). The same situation is recalled at the close of the first fragment: "Por eso vine a Comala ("That was why I had come to Comala"), ${ }^{8}$ and on several occasions again up to fragment 36 : „Vine a buscar a Pedro Páramo, que según parece fue mi padre " (»I came to find Pedro Páramo, who they say was my father «). Juan Preciado's narrative is interrupted by fragments belonging to different sequences and characterised by a different, third-person narrative mode, with no trace of a reference to a precise narrative situation (fragments 6, 7, 8, 10 and 12: Pedro Páramo's adolescence in Comala; fragments 13 to 16: death of Miguel Páramo, Pedro Páramo's illegitimate son; fragments 18 to 23: establishing Pedro Páramo's dominance, with his marriage to Dolores Preciado and the assassination of Toribio Aldrete). The first part ends at the beginning of fragment 36, where we learn that Juan Preciado's narrative takes place in the context of a dialogue - and thus in a communicational context - between Juan Preciado and Dorotea, an elderly woman who had been buried after him in the same tomb:

- ¿Quieres hacerme creer que te mató el ahogo, Juan Preciado? Yo te encontré en la plaza, muy lejos de la casa de Donis, y junto a mí también estaba él, diciendo que te estabas haciendo el muerto. Entre los dos te arrastramos a la sombra del portal, ya bien tirante, acalambrado como mueren los que mueren muertos de miedo. De no haber habido aire para respirar esa noche de que hablas, nos hubieran faltado las fuerzas para llevarte y contimás para enterrarte. Y ya ves, te enterramos.

- Tienes razón, Doroteo. ¿Dices que te llamas Doroteo?

- Da lo mismo. Aunque mi nombre sea Dorotea. Pero da lo mismo.

- Es cierto, Dorotea. Me mataron los murmullos.

(Rulfo 2007, 117)

"Are you trying to make me believe you drowned, Juan Preciado? I found you in the town plaza, far from Donis's house, and he was there, too, telling me you were playing dead. Between us we dragged you into the shadow of the arches, already stiff as a board and all drawn up like a person who'd died of fright. If there hadn't been any air to breathe that night you're talking about, we wouldn't have had the strength to carry you, even less bury you. And, as you see, bury you we did."

${ }^{7}$ An earlier version of this passage, published in the journal Las Letras Patrias in 1954, contains no reference of this sort: "Fui a Tuxcacuexco porque me dijeron que allá vivia mi padre, un tal Pedro Páramo. Mi madre me lo dijo. Entonces le prometi que iría a verlo en cuanto ella muriera", etc. (see Zepeda 2005, 78); "I went to Tuxcacuexco because I was told that my father, a certain Pedro Páramo, lived there. It was my mother who told me. So I promised her that I would go and see him when she died" (my translation).

${ }^{8}$ Rulfo $(2007,65)$ and Rulfo $(1994,3)$.

9 Rulfo $(2007,119)$ and Rulfo $(1994,60)$. 
"You're right, Doroteo. You say your name's Doroteo?»

"It doesn't matter. It's really Dorotea. But it doesn't matter."

"It's true, Dorotea. The murmuring killed me.«

(Rulfo 1994, 58)

In the second part, in which references back to the dialogue between Juan Preciado and Dorotea also intervene (fragments 38, 42, 52, 55 and 64), the main interest centres on the stories of Pedro Páramo and Susana San Juan, Pedro Páramo's last wife. These are related in the third person, either objectively or from different characters' points of view, or in the first person by Susana San Juan herself. Here are the opening lines to fragment 39 (the possessive "su « in "su puerta « refers to Pedro Páramo):

Llamaron a su puerta; pero él no contestó. Oyó que siguieron tocando todas las puertas, despertando a la gente. La carrera que llevaba Fulgor - lo conoció por sus pasos - hacia la puerta grande se detuvo un momento, como si tuviera intenciones de volver a llamar. Después siguió corriendo.

Rumor de voces. Arrastrar de pisadas despaciosas como si cargaran algo pesado.

Ruidos vagos.

(Rulfo 2007, 125)

They pounded at his door, but he didn't answer. He heard them knock at door after door, waking everyone around. Fulgor - he knew him by his footsteps - paused a moment as he hurried toward the main door, as if he meant to knock again. Then kept running.

Voices. Slow, scraping footsteps, like people carrying a heavy load.

Unidentifiable sounds.

(Rulfo 1994, 66)

In both parts of the text, there is a massive presence of dialogue (either involving Juan Preciado or overheard by him, or perceived by him in an unnatural manner, according to his own commentaries in the first part) as well as monologue (reported, attributed to Juan Preciado's mother or remembered by him in the first part). Fragments 16 and 19 of the first part, as well as several fragments in the second part, also contain passages of free indirect discourse, used to represent the thoughts of certain characters (Father Rentería, the priest in Comala, Fulgor Sedano, the administrator at La Media Luna, Susana San Juan, Gerardo Trujillo, Pedro Páramo’s lawyer, Abundio Martínez, another of Pedro Páramo’s illegitimate sons).

\section{Pedro Páramo According to Communicational Theories of Narrative (Critical Reception of Pedro Páramo)}

It can reasonably be supposed that all critics, whether they draw on communicational theories of narrative or non-communicational or poetical theories of fictional narrative, do or would agree to consider Juan Preciado as the fictional narrator, that is, the character who has the status of narrator in the fictional world, in the first part of the novel (except in fragments 6 to $8,10,12$ to 16,18 to 23, mentioned 
already). ${ }^{10}$ The comparison only really becomes interesting when the question is asked: who is the narrator of the second part of the novel (as well as fragments 6 to $8,10,12$ to 16,18 to 23 in the first part)? As well, perhaps, as the question: is the fictional narrator of the second part of the novel also the reporter of the dialogue between Juan Preciado and Dorotea, and thus of Juan Preciado's narrative in the first part of the novel? The second question can also be formulated in the following way: is the fictional narrator of the second part of the novel responsible for the arrangement of the novel as a whole, presented as a montage of real documents?

The answers given to the first question in critiques of Pedro Páramo are unanimous on the presence of a fictional narrator in the second part of the novel although they name, and in some cases describe, the fictional narrator in a variety of ways. The term most often encountered is that of 'third-person narrator ( 'narrador en tercera persona $).{ }^{11}$ Its meaning is determined within the opposition between ffirst-person narrator $\triangleleft$ and third-person narrator ${ }^{12}$ (an opposition based on the opposition between 'first-person narratives and 'third-person narratives, itself stemming historically from the opposition between ifirst-person novel and sthird-person novel ${ }^{13}$ ). 'Third-person narrator in this context means the snarrator of a third-person narrative or the narrator of a narrative which is not in the first person'. However, it is evident that the term itself is meaningless. As Genette writes in Narrative Discourse (1972, transl. 1980), a narrator "can be in his narrative (like every subject of an enunciating in his enunciated statement) only in the first person [...] (Genette 1980, 244; meaning: a narrator can only refer to himself using a first-person pronoun; while he may not refer to himself, he nevertheless remains a first person who, if he is not actualized, is at least able to be actualized as such). Another term which is often encountered is that of somniscient narrator (snarrador omniscientes). ${ }^{14}$ Unlike the preceding one, this term sometimes elicits commentary, which essentially aims at limiting its use to certain passages or textual

${ }^{10}$ Aronne-Amestoy $(1986,57)$ speaks of Juan Preciado as a "pseudo-narrator" ("seudonarrador «), because he does not satisfy the condition of survival associated with a narrator of a traditional firstperson fictional narrative (the narrator must have survived after the end of the story in order to be able to tell it). The pseudo-narrator is nevertheless a fictional narrator in the sense in which the term is used here.

${ }^{11}$ See for example Luraschi (1976, 7, 15-21, 25), González Boixo (1980, 152, 153-169 et passim), González Boixo $(2007,19,22,31)$, Aronne-Amestoy $(1986,53)$, De Toro $(1992,204,215-217$ et passim), Zepeda (2005, 7 et passim), Anderson $(2007,5)$.

12 See in particular Luraschi (1976, 7-15, 15-21), González Boixo (1980, 153-169, 169-178), De Toro (1992, 215-217, 217-221).

13 See the text box "Les termes ’roman à la première personner et ’roman à la troisième personne« in the introduction to Patron $(2009,15-16)$.

${ }^{14}$ See for example Luraschi 1976, 16, 17, 18; González Boixo 1980, 153, 154, 159, 164; Bradu 1995, 21; Jiménez de Báez 1990, 131; De Toro 1992, 203, 204, 215, 216; Llarena 1997, 108; PalaisiRobert 2003, 110; Anderson 2007, 5. 
manifestations. ${ }^{15}$ In Claves narrativas de Juan Rulfo (1980), José Carlos González Boixo distinguishes between `omniscient narrator and `equiscient narrator ( 'narrador equiscienter),${ }^{16}$ the second term being used for narrative passages ' with point of view ( third-person narratives which express the point of view of a character, or ifigural narrative to use Franz Stanzel's terminology, or narrative swith internal focalization in Genette's terminology. ${ }^{17}$ ) The following terms can also be found: ‘objective narrator ( (snarrador objetivo $),{ }^{18}$ 'hidden or >concealed narrator $($ (snarrador

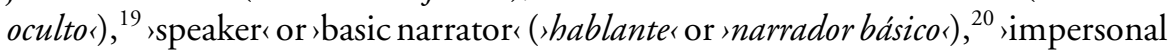
narrator $\triangleleft$ or heterodiegetic narrator $\iota^{21}$

All the terms which have just been mentioned aim to replace older terms such as

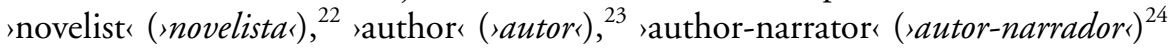
or >omniscient author ( (autor omnisciente) $){ }^{25}$ seen as supporting outmoded theoretical conceptions. For González Boixo, reading a novel implies a double communicative situation taking place on two ontologically distinct levels: »The reader and the author are both two external elements, and their importance is due to the fact that the author is the creator of the literary message and that the reader, as the receiver of the message, must be capable of receiving it«; within the literary message, »both disappear as such (Juan Rulfo and the reader $\mathrm{x}$ ) and are transformed into fictional beings; the author becomes the narrator and the reader $\mathrm{x}$ the ideal reader for whom the narrative is constructed [el autor se transformará en el narradory el lector $x$, en el lector ideal para quien se construye la narración] « ${ }^{26}$ According to this concep-

15 See in particular González Boixo 1980, 158-164. The idea of »linking omniscience" (»omnisciencia de enlace", ibid., 159-161), as well as that of "poetical omniscience» (»omnisciencia de carácter poético", ibid., 161 - 163), stem from Ilse Adriana Luraschi (see Luraschi 1976, 16-17, 21, 26-27). See also De Toro 1992, 215-216.

${ }^{16}$ Strictly speaking, González Boixo borrows the distinction from Oscar Tacca (see Tacca 1973, 61; González Boixo 1980, 153). The term snarrador equiscienter is taken up and attributed to González Boixo in Espinosa-Jácome 1996, 33.

17 See Stanzel 1971, 23 et passim; Stanzel 1984, 5 et passim; Genette 1980, 189 et passim. González Boixo's equiscient narrator also corresponds to the narrator with limited omnisciencer referred to by numerous Anglo-Saxon critics and theorists.

18 See for example Aronne-Amestoy 1986, 5.

19 See for example Aronne-Amestoy 1986, 54; Palaisi-Robert 2003, 111.

${ }^{20}$ See Carreño 2004, 5 et passim. These terms stem from Félix Martínez Bonati (see Martínez Bonati 1981, 29, 35 et passim).

${ }^{21}$ See Palaisi-Robert 2003, 110. The latter term is from Genette (see Genette 1980, 245).

22 See Blanco Aguinaga 2003, 36.

${ }^{23}$ See for example Frenk 2003, 51; Rodríguez Monegal 2003, 124; Ortega 1976, 11; Ortega Galindo 1984, 247, 248, 249.

${ }^{24}$ See for example Leal 1995, 102, Ortega Galindo 1984, 249.

25 See for example Leal 1995, 100; Ortega 1976, 10.

${ }^{26}$ González Boixo 1980, 151; my translation. In the introduction to Patron 2009, 23-24, I comment, in relation to Barthes on the confusion between internal characteristics (within the linguistic or semiological opposition between sexternal and internalı) and ffictional characteristics (within the ontological opposition between real and (fictional $\varsigma$ ). This confusion is also at work here. 
tion, to say that the author is telling the story in the second part of Pedro Páramo would be to confuse the level of reality with that of fiction. For Alejandro Carreño, "the term rauthor-narrator is ambiguous and, moreover, lacks any solid theoretical substance«. He refers to the theoretical views of Martinez Bonati to affirm that »the narrator is made of words, [and] absents himself in the (imaginary) language of what is communicated " (Carreño 2004, 5; my translation). Carreño also quotes Martínez Bonati: "To the extent that what is communicated is (imaginary) language, the situation of imaginary linguistic communication - that is, the immanent meaning of the sentences - includes neither author nor reader, but is a transcendent object for both" (Martínez Bonati 1972, 131; my translation; see also Martínez Bonati 1981, 81), as well as Wolfgang Kayser: „For many readers of novels, the narrator is none other than the author. Such readers fail to understand that the narrator is also a fictional product, and is himself part of the poetical reality he recounts and considers his sole reality." (Kayser 1970, 466; my translation)

No answer to the second question (is the fictional narrator of the second part of the novel also the reporter of the dialogue between Juan Preciado and Dorotea, and thus of Juan Preciado's narrative in the first part of the novel?) is provided in critical works on Pedro Páramo. It is as if, having ousted the author in favour of the narrator, seen as a fictional being, the analyst were then obliged to bring him back to account for facts pertaining to the arrangement of the novel. Indeed it is very difficult to see the arrangement of the novel Pedro Páramo as a fictional imitation of a montage of real documents.

Presenting the second part of Pedro Páramo as if it were due to a fictional narrator in the same way as Juan Preciado's narrative in the first part of the novel raises a certain number of problems (none of which, it might be noted in passing, are dealt with in critical works on Pedro Páramo). I will divide these problems into three groups: 1) problems with the internal coherence of the critical discourse; 2) problems with the organisation of the task of interpretation;3) problems with falsifying erroneous interpretations.

Claiming that the second part of Pedro Páramo is due to a fictional narrator in the same way as Juan Preciado's narrative in the first part of the novel confuses two profoundly distinct conceptions of the fictional and fictionality. In the first part of the novel, the narrator designated by $>\mathrm{K}$ is presented as a character in the fiction ("Vine a Comala, porque me dijeron que acá vivia mi padre, un tal Pedro Páramo", Rulfo 2007, 65). The narrator is obviously fictional and his narrative situation is also fictional (Dorotea to Juan Preciado: "Yya ves, te enterramos", ibid., 117). Fictional , here, means screated by the author and giving rise to imagination on the part of the reader. In the second part of the novel, not only is the narrator not a character within the fiction, but there is no mention of his very existence. If he is considered to be fictional, it is only as a result of a standard argument, which can today be seen as fallacious, according to which the narrating of a fictional narrative, 
composed of fictional events and characters, necessarily implies the presence of a fictional narrator. ${ }^{27}$ 'Fictional, here, does not mean screated by the author`, but rather screated by a theoretical argument concerning the workings of fiction`. I might add that if the narrator is to promote imagination on the part of the reader, the imagining in question would often contradict that of the fictional content of the story. Take, for example, the opening lines of fragment 15 , which is part of the sequence concerning Miguel Páramo's death in the first part of the novel:

Un caballo pasó al galope donde se cruza la calle real con el camino de Contla. Nadie lo vio. Sin embargo, una mujer que esperaba en las afueras del pueblo contó que habia visto el caballo corriendo con las piernas dobladas como si se fuera a ir de bruces. Reconoció el alazán de Miguel Páramo. Y hasta pensó: "Ese animal se va a romper la cabeza. "Luego vio cuando enderezaba el cuerpo y, sin aflojar la carrera, caminaba con el pescuezo echado hacia atrás como si viniera asustado por algo que habia dejado allá atrás.

Esos chismes llegaron a la Media Luna la noche del entierro, mientras los hombres descansaban de la larga caminata que habian hecho hasta el panteón.

(Rulfo 2007, 89-90)

A horse galloped by the place where the main street crosses the road to Contla. No one saw it. Nevertheless, a woman waiting on the outskirts of the village told that she had seen the horse, and that its front legs were buckled as if about to roll head over hooves. She recognized it as Miguel Páramo's chestnut stallion. The thought had even crossed her mind that the animal was going to break its neck. Then she saw it regain its footing and without any interruption in stride race off with its head twisted back, as if frightened by something it had left behind.

That story reached to the Media Luna on the night of the burial, as the men were resting after the long walk back from the cemetery.

(Rulfo 1994, 28)

The reader cannot imagine, at the same time, that the event constituted by the horse passing by was witnessed by nobody ("Nadie lo vio"), even though a character recounted having witnessed it ("Sin embargo, una mujer [...] contó que había visto el caballo"), and that the fictional narrator, if indeed there is a fictional narrator, himself witnessed the event. The opening lines of fragment 59 could also be mentioned, recalling "una de esas lunas tristes que nadie mira, a las que nadie hace caso" ("one of those sad moons that no one looks at or pays attention to «), ${ }^{28}$ as well as all the scenes which are supposed to have taken place with no witnesses apart from the characters mentioned (the dialogue between Father Rentería and his niece in fragment 14, Father Rentería's insomnia in fragment 16, the interview between Fulgor Sedano and Dolores Preciado in fragment 21, Father Rentería's confession to the Contla priest or Dorotea's to Father Rentería in fragment 40, the night spent by Damiana

${ }^{27}$ This line of reasoning is at work in the quotes from Martínez Bonati and Kayser cited above. It is contradicted, for example, by Searles's (1979) analysis, first published in 1975. On Searle and narratology, Chapter 5 of Patron (2009, 99-134).

${ }^{28}$ Rulfo $(2007,160)$ and Rulfo $(1994,105)$. 
Cisneros in fragment 59, or Pedro Páramo's in fragment 67, or Pedro Páramo’s death in fragment 69).

The second group of problems concerns the organisation of the task of interpretation. In a first-person fictional narrative, such as Juan Preciado's narrative in the first part of Pedro Páramo, all the formal elements contribute to defining the fictional narrator and thus lend themselves to an interpretation which goes beyond the formal level. As soon as the second part of Pedro Páramo is seen as a firstperson fictional narrative in which the $\triangle \mathrm{I}$ is erased, but could be reinstated, all the formal elements must also be seen as contributing toward defining the fictional narrator and lending themselves to an interpretation going beyond the formal level. We are therefore led to ask a certain number of questions, beginning with the question: why does the fictional narrator systematically refuse to use the personal pronoun, $\mathrm{L}$ ? Other questions include (to summarise, I am presenting them in the form of a list, accompanied by representative extracts from the second part of Pedro Páramo):

How can the fact be explained that the fictional narrator has perfect, integral knowledge of the thoughts and feelings of certain characters? See, for example, the following extract from fragment 56 :

Si al menos fuera dolor lo que sintiera ella, y no esos sueños sin sosiego, esos interminables y agotadores sueños, él podría buscarle algún consuelo. Asi pensaba Pedro Páramo, fija la vista en Susana San Juan, siguiendo cada uno de sus movimientos. ¿Qué sucedería si ella también se apagara cuando se apagara la llama de aquella débil luz con que él la veía?

(Rulfo 2007, 157)

If only she were suffering pain, and not these relentless, interminable, exhausting dreams, he could find some way to comfort her. Those were Pedro Páramo's thoughts as he stood watching Susana San Juan, following her every movement. What would he do if she died like the flame of the pale light that allowed him to watch her?

(Rulfo 1994, 101)

Or the following extract from the final fragment:

"Con tal de que no sea une nueva noche", pensaba él.

Porque tenia miedo de las noches que le llenaban de fantasmas la oscuridad. De encerrarse con sus fantasmas. De eso tenía miedo.

(Rulfo 2007, 178)

"So there won't be another night «, he thought.

Because he feared the nights that filled the darkness with phantoms. That locked him in with his ghosts. That was his fear.

(Rulfo 1994, 124)

How can it be explained that he remembers a priori meaningless details about events that occurred a long time ago, the private nature of which would seemingly need to exclude the presence of witnesses? Take, for example, the following extract from fragment 37 (according to the chronology drawn up by González Boixo, the events 
in questions took place nineteen years before Pedro Páramo's death, recounted in the last fragment):

Fulgor Sedano sintió el olor de la tierra y se asomó a ver cómo la lluvia desfloraba los surcos. Sus ojos pequeños se alegraron. Dio hasta tres bocanadas de aquel sabor y sonrió hasta enseñar los dientes. "Vaya! - dijo - . Otro buen año se nos echa encima." Y añadió: "Ven, agüita, ven. ¡Déjate caer hasta que te canses! Después córrete para allá, acuérdate que hemos abierto a la labor toda la tierra, nomás para que te des gusto."

$Y$ soltó la risa.

(Rulfo 2007, 121)

Fulgor Sedano breathed in the scent of fresh earth and looked out to see how the rain was penetrating the furrows. His little eyes were happy. He took three deep gulps, relishing the savor, and grinned till his teeth showed.

"Ahhhh!", he said. "We're about to have another good year." And then added: "Come on down, rain. Come on down. Fall until you can't fall anymore! And then move on. Remember that we worked the ground just to pleasure you."

And he laughed aloud.

(Rulfo 1994, 61-62)

How could it be explained, either, that he is never mistaken in his claims or interpretations, or that he knows what is happening at the same time in two different places, or that he denies the receiver information of which he is clearly in possession? Take the following extracts from fragments 57, 67-68 and 37:

El licenciado Gerardo Trujillo salió despacio. Estaba ya viejo; pero no para dar esos pasos tan cortos, tan sin ganas. La verdad es que esperaba una recompensa.

(Rulfo 2007, 158)

Gerardo Trujillo, lawyer, left very slowly. He was old, but not so old he had to walk so haltingly, so reluctantly. The truth was that he had expected a reward.

(Rulfo 1994, 102)

Pedro Páramo siguió moviendo los labios, susurrando palabras. Después cerró la boca y entreabrió los ojos, en los que se reflejó la débil claridad del amanecer.

Amanecía.

[blank space]

A esa misma hora, la madre de Gamaliel Villalpando, doña Inés, barría la calle frente a la tienda de su hijo, cuando llegó y, por la puerta entornada, se metió Abundio Martínez.

(Rulfo 2007, 173)

Pedro Páramo's lips kept moving, whispering words. Then as he pressed his lips together, he opened his eyes, where the pale light of dawn was reflected.

Day was beginning.

[blank space]

At the same hour, doña Inés, the mother of Gamaliel Villalpando, sweeping the street in front of her son's store, saw Abundio Martínez push the half-open door and go inside.

(Rulfo 1994, 118) 
Después [Miguel Páramo] se quedó pensando si aquella mujer no le serviría para algo. Y sin dudarlo más fue hacia la puerta trasera de la cocina y llamó a Dorotea:

- Ven para acá, te voy a proponer un trato - le dijo.

Yquién sabe qué clase de proposiciones le haría, lo cierto es que cuando entró de nuevo se frotaba las manos [...].

(Rulfo 2007, 122)

He [Miguel Páramo] sat and thought for a while, wondering how the woman might be of use to him. Then without further hesitation he went to the back kitchen door and called Dorotea: "Come here a minute, I've got a proposition to make you", he said.

Who knows what deal he offered her; the fact is that when he came inside he was rubbing his hands.

(Rulfo 1994, 63; the reader learns later on that Miguel Páramo has asked Dorotea to act as his go-between)

However hard one might look, there is no response to be found to such questions within the fiction. The only adequate explanation for the formal peculiarities of the extracts in question is as choices made by the author for technical or artistic reasons. The questions listed above are therefore false questions, which detract from the real questions to be asked (for example, how does the author manage to make Miguel Páramo both his father's double and a character with his own defining traits and his own place within the system of characters in the novel?)

To illustrate the third group of problems, which concerns the falsification of erroneous interpretations, I will draw on an example taken from Lida Aronne-Amestoy in Utopía, paraíso e historia. Inscripción del mito en García Márquez, Rulfo y Cortázar (1986). In the chapter devoted to Rulfo's novel, in a section called »Perspectivation " (»Perspectivación «), Aronne-Amestoy develops a comparison between the narrator of the second half of Pedro Páramo and the character of Pedro Páramo himself. She writes:

The narrator is to the level of narrating what Pedro Páramo is to the level of what is narrated: even though they only appear to exist in and through the perspective of the protagonists (it should be kept in mind that Pedro Páramo is entirely reconstituted from the memories of those who knew him), they are both present as powerful, fully constituted images in the text - in opposition to the fragmentary, blurred image of the others. They both function as an ever-present absence [Ambos funcionan como una ausencia omnimoda].

(Aronne-Amestoy 1986, 54-55) ${ }^{29}$

I will pass over the two propositions introduced in the form of presuppositions: "Pedro Páramo only exists in and through the perspective of the protagonists" and »Pedro Páramo is entirely reconstituted from the memories of those who knew him«. These propositions are false and numerous examples would enable

29 The dictionary translates somnimodo, - $a$ : as sall-embracing; absolute. However, a few lines further on Aronne-Amestoy speaks of the "obvious absence [of the narrator] « ("la evidencia de [la] ausencia [del narrador] ") or of a narrator "omnipresent in the reader's mind " ("omnipresente en la consciencia de la lectura [sic] «), leading me to translate "una ausencia omnimoda» by "an ever-present absence». 
this to be shown ${ }^{30}$ (I do not mean by this that Pedro Páramo does not also exist in and through the perspective of the other characters, nor that his personality is not partially reconstituted from the memories of those who knew him; once more, I refer to examples from the text ${ }^{31}$ ). It seems to me more important to note that the narratorial theme has never been less visible than in the second half of Pedro Páramo, yet never has it been affirmed with so much force, nor interpreted so resolutely: the hegemony of the narrator is founded here on his absence. The problem is that the proposition "the narrator functions as an ever-present absence» is not a falsifiable proposition. Any fact or any absence of a fact can be interpreted as supporting this proposition.

\section{Pedro Páramo According to Non-communicational or Poetic Theories of Fictional Narrative}

If any critical works drawing on non-communicational or poetic theories of fictional narrative existed, they would clearly consider, one the one hand, that the first part of the novel (apart from fragments 6 to $8,10,12$ to 16 and 18 to 23) is narrated by a fictional narrator (with potential variations on the questions of whether the first part is the fictional imitation of a speech act or act of communication, or whether the revelation contained in fragment 36 leads us to consider it as such retrospectively), and on the other hand, that the second half of the novel (along with the fragments mentioned above) forms a narratorless narrative or collection of narratives. In other words, they would consider that there is no narrative device, in the second part of Pedro Páramo, comparable to the one defining the first part. As Banfield writes in Unspeakable Sentences (1982):

If narration contains a narrator, this » $[$ « is not speaking, quoted by the author; he is narrating. If it does not, then the story "tells itself «, as Benveniste has it. In neither case does narration entail addressing an audience. Rather, it is of its nature to be totally ignorant of an audience, and this fact is reflected in its very language.

(ibid., 179; The expression cited in quotation marks refers to Benveniste 1971, 208)

It can be noted, first of all, that these considerations agree more closely than the preceding ones with the semantic and pragmatic intentions of the author as expressed in various texts and interviews. I have in mind, for example, the 1985 text in which Rulfo writes: »I have nothing to say against my critics. It was difficult

${ }^{30}$ See fragments $6,7,8,10,12,13,19,22,23,37,39,40,43,44,46,51,53,54,56-63,65-69$. All these fragments contain either purely narrative sentences referring to Pedro Páramo, or sentences of free indirect discourse where the subject of consciousness is Pedro Páramo, or dialogues involving Pedro Páramo. In other words, they contain all the linguistic and textual means needed to create a fictional character independently from the perspective of other characters.

${ }^{31}$ See fragments $1,2,9,10,11,15,18,19,20,21,22,25,26,31,40,42,45,57,58,59,62$. 
to accept a novel which presented itself, with apparent realism, as the story of a cacique, whereas it is in reality the story of a village: a dead town where everybody is dead. Including the narrator " (Rulfo 1985, 2; my translation). »The narrator " (»el narrador ") refers here to Juan Preciado. At no point did Rulfo write or suggest that another narrator takes over from the latter from the point where he finishes his narrative. Rulfo also confides, elsewhere, concerning the origin of the novel, that: "Writing tales has been good discipline for me. It has made me see that it is necessary for the author to disappear and for him to let his characters speak freely [...] « (Rulfo in Benitez 2003, 546). In several texts and interviews he describes his work on Pedro Páramo as a task involving deleting any traces of the author's presence ("I eliminated all the digressions and completely erased any authorial intrusions [las intromisiones delautor] «, Rulfo 1985, 2; my translation). At no point does he write or suggest that he strove to disappear as author all the better to reappear, in the second part of the novel, as narrator.

It can also be noted that the considerations drawing on non-communicational or poetic theories of fictional narrative correspond better than the preceding ones to the cognitive and imaginative experience of readers, such as they can be deduced from our own experience as readers, as well as from certain terms used in critical appraisals of Pedro Páramo (’objective narrator`, ’hidden` or 'concealed narrator‘, or impersonal narrators, for example. ${ }^{32}$ ) It can be affirmed that, apart from exceptional reading experiences, the reader knows that Pedro Páramo has an author. There is therefore no need to postulate another agent to account for the existence of the novel as a real entity in the world. This is clearly so for both parts of the novel. If it is now asked what the reader imagines upon reading Pedro Páramo, a distinction needs to be drawn between the first and the second part of the novel. First part: as readers we know that the author is responsible for the existence of the novel (or for this part of the novel, if we are not reading it for the first time), but we also imagine that there is somebody else responsible within the fiction. Our imagining of the characters and events of the fiction is mediated by the primary imagining of the narrative being related by a character in the fiction. Second part: the reader knows that the author is responsible for the existence of this part, but we do not imagine that somebody else is responsible within the fiction. We imagine the characters and events of the fiction directly (with the possible exception of several passages where we perceive a fictional narrator effect: we have already come across "Un caballo pasó al galope donde se cruza la calle real con el camino de Contla" (Rulfo 2007, 89; my emphasis), we might also recall "Justina Díaz, cubierta por paraguas, venia por la calle derecha que viene de la Media Luna [...]" (Rulfo

\footnotetext{
32 See above, note 19,20 and 22.
} 
2007, 143, my emphasis ${ }^{33}$ ). The portrait of Eduviges Dyada in fragment 9, and the beginning of fragment 65, which described Pedro Paramo's attitude following the death of Susana San Juan, illustrate the difference between the two parts:

Sin dejar de oírla, me puse a mirar la mujer que tenia frente a mi. Pensé que debia haber pasado por años difíciles. Su cara se transparentaba como si no tuviera sangre, y sus manos estaban marchitas; marchitas y apretadas de arrugas. No se le veían los ojos. Llevaba un vestido blanco muy antiguo, recargado de holanes, y del cuello, enhilada en un cordón, le colgaba una María Santísima del Refugio con un letrero que decía: "Refugio de pecadores."

(Rulfo 2007, 79)

As I listened to her drone on, I studied the woman before me. I thought she must have gone through some bad times. Her face was transparent, as if the blood had drained from it, and her hands were all shriveled, nothing but wrinkled claws. Her eyes were sunk out of sight. She was wearing an old-fashioned white dress with rows of ruffles, and around her neck, strung on a cord, she wore a medal of the María Santísima del Refugio with the words »Refuge of Sinners".

(Rulfo 1994, 16)

Pedro Páramo estaba sentado en un viejo equipal, junto a la puerta grande de la Media Luna, poco antes de que se fuera la última sombra de la noche. Estaba solo, quizá desde hacía tres horas. No dormía. Se habia olvidado del sueño y del tiempo: "Los viejos dormimos poco, casi nunca. A veces apenas si dormitamos; pero sin dejar de pensar. Eso es lo único que me queda por hacer. "Después añadió en voz alta: "No tarda ya. No tarda."

(Rulfo 2007, 172)

Pedro Páramo was sitting in an old chair beside the main door of the Media Luna a little before the last shadow of night slipped away. He had been there, alone, for about three hours. He didn't sleep anymore. He had forgotten what sleep was, or time. »We old folks don't sleep much, almost never. We may drowse, but our mind keeps working. That's the only thing I have left to do." Then he added, aloud: »It won't be long now. It won't be long.«

(Rulfo 1994, 117)

The direct imagining of the reader in the second half of the novel also concerns the thoughts and feelings of the fictional characters. When we read sentences like "Estaba solo, quizá desde hacía tres horas" or "Se había olvidado del sueño y del tiempo", or Pedro Páramo's monologue, as readers we do not wonder how the fictional narrator has knowledge of these events, because we do not imagine a fictional narrator who might have knowledge of such events and relate them or report in the form of direct discourse. What the reader imagines is that Pedro Páramo has been alone, or feels he has been alone for about three hours, that he has lost the ability to sleep and all sense of time, and is thinking: "Los viejos dormimos poco", etc. This does not mean that the reader is unable to appreciate the beauty of the sentence "Se habia olvidado del sueño $y$ del tiempo", but our appreciation detracts us from the fiction as such.

33 The presence in the same sentence of verbs both in the present and the past is not rendered in the English translation: "Beneath her umbrella Justina Díaz makes her way down the straight road leading from the Media Luna [...] (Rulfo 1994, 86) 
Non-communicational or poetic theories of fictional narrative make a clear distinction between elements pertaining to the content of the fictional representation (the characters and the events, the narrator, if there is one) and elements pertaining to the means employed to help construct this representation (language, style, the composition of the text on different levels). Banfield writes, for example, regarding the style of the author: "[...] style approached in this way is not on par with those aspects of style which create the intentional construct which is a fictional subjectivity. A writer may leave his signature in his writing - it may even contribute a major proportion of what is valued in it - but this is not what his writing creates [...] « (Banfield 1982, 253; on textual composition, see Banfield 1978, 297-297, note 6) This distinction is more pertinent for the analysis and interpretation of the novel than the postulate of a double situation of communication and a total overlap between the real communication between author and reader and the fictional communication between narrator and narratee, on which communicational theories of fictional narrative are based. This is what I would like to show here using two examples taken from Pedro Páramo.

In the first part of the novel, the distinction between elements pertaining to the content of the fictional representation and those pertaining to the means employed to help construct this representation allows a certain number of facts to be accounted for in a simpler, more economical and also more convincing manner than the communicational postulate: for example, the fact that Juan Preciado sonceals fact, from fragment 1 to fragment 35, that he is telling his story to someone, or that he is telling it after his death (in reality, it is not a matter of sconcealment 'narrative unreliability', to use a favourite term in Anglo-Saxon theory and criticism, but simply of an authorial strategy, the goal of which is to orchestrate the surprise caused by fragment 36); or the fact that the dialogue in fragment 30 between Donis and his sister is >reported in its entirety and in an extremely precise fashion, even though this dialogue describes the rreporter, Juan Preciado, as unable to hear or memorise anything more than snatches of dialogue ("Se rebulle sobre si mismo como un condenado. [...] ;Levántate, Donis! Miralo. Se restriega contra el suelo, retorciéndose. Babea «, Rulfo 2007, 109; »He's thrashing around like he's damned. [...] Get up, Donis! Look at him. Look how he's writhing there on the ground, twisting and turning. He's drooling «, Rulfo 1994, 49). Once more, it is not a matter of concealment or unreliability on the part of the narrator, but simply of authorial choice, which takes precedence over the option of plausibility for this passage in Juan Preciado's narrative. As regards the second part of the novel, attention could be drawn in the same way to the fact that the dialogue in fragment 66 between Damasio, known as El Tilcuate, and Pedro Páramo is in reality a false dialogue, or rather a montage of dialogues involving the same interlocutors, in the same place, but at different periods, as is shown by the content of El Tilcuate's contributions (»El Tilcuate siguió viniendo: - Ahora somos carrancistas. — Está bien. — Andamos con mi 
general Obregón. - Está bien. - Allá se ha hecho la paz. Andamos sueltos. - Espera. No desarmes a tu gente. Esto no puede durar mucho. - Se ha levantado en armas el padre Rentería. ¿Nos vamos con él, o contra él? - Eso ni se discute. Ponte al lado del gobierno«, Rulfo 2007, 171; „El Tilcuate continued to report: , We're with Car-

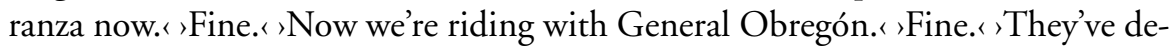
clared peace. We're dismissed. , Wait. Don't disband your men. This won't last long. «Father Rentería’s fighting now. Are we with him or against him? «No question. You're on the side of the government.«, Rulfo 1994, 117 ${ }^{34}$ ). The fact could also be mentioned that other organisational networks are substituted for the logicotemporal order of events: recurrent themes and motifs (rain or water in fragments 6 , 8 and 12, associated with Pedro Páramo's adolescence in Comala, rain once more in fragments 37, 47, 48, 49 and 50; shooting stars in fragments 15, 16 and 40, associated with Miguel Páramo’s death); echoes and intratextual references (»They’ve killed your father « in fragments 12 and 39; Pedro Páramo's monologue on Susana San Juan's death in fragment 67, referring back to the same character's monologue concerning the young Susana San Juan's departure from Comala in fragment 10); multiplicity and variability of points of view on certain events (Miguel Páramo's death in fragments 11, 15 and 39; the assassinations committed by Pedro Páramo after his father's death in fragments 39 and 42), etc. These networks go beyond any one character's faculty for memorizing as well as the mastery of a narrator or organizer of the narrative belonging to the fictional world.

The distinction between elements pertaining to the content of the fictional representation and elements pertaining to the means employed to help construct this representation also enables us to do without the hypothesis of an omniscient fictional narrator, along with the different types of omniscience in the critical repertory: 'neutral omnisciences, including 'neutral poeticised omnisciences, straditional omniscience and omniscience combined with free indirect style (»Omnisciencia neutra : neutra poetizada, tradicional, combinada con estilo indirecto libre», see Luraschi 1976, 16-20); >omniscience of the traditional type (»Omnisciencia de tipo tradicional«), linking omniscience (»Omnisciencia de enlace«), ’poetic omniscience (»Omnisciencia de carácter poético»), ssetting-related omniscience (»Omnisciencia ambiental $«$ ) $;{ }^{35}$ and finally, limited omnisciences, corresponding to Tacca’s and González Boixo's sequisciencer (González Boixo 1980, 153 et passim. See also above, note 17 and 18.) Poetry, free indirect discourse, narrative information to which the characters have no access (>mniscience of the traditional type), introducing dialogues and monologues (,linking omniscience), creating a setting, representing characters' points of view using different linguistic and textual means (requisciences): all are seen as due to authorial activity and are not considered as fictional.

\footnotetext{
${ }^{34}$ I am placing contributions which appear in both editions on separate lines together on the same line.

35 See González Boixo (1980, 156-164). See also above, note 16.
} 
A relation which is pertinent to the interpretation of the content of the fictional representation can thus be established between what Rulfo calls the "voices" $(\text { (»oces« })^{36}$, »echoes« (»ecos») $)^{37}$ or »murmuring $(\text { "murmullos })^{38}$, in other words, the speech of the dead heard or perceived by the narrator, Juan Preciado, in the village of Comala, and Juan Preciado's narrating, which is also a form of speech rafter death. This speech of the people, freed by death, and the narrating of the son who has come to take his mother's place in the cemetery of Comala, are opposed to the discourses of hegemony and power, whether temporal (incarnated by Pedro Páramo) or spiritual (incarnated by Father Rentería), which appear in the second half of the novel (as well as in fragments 16, 19, 22 and 23 in the first part). Two final examples follow:

- Será lo que usted diga, don Pedro; pero esa mujer que vino ayer a llorar aqui, alegando que el hijo de usted [Miguel] le habia matado a su marido, estaba de a tiro desconsolada. Yo sé medir el desconsuelo, don Pedro. Yesa mujer lo cargaba por kilos. Le ofrecí cincuenta hectolitros de maiz para que se olvidara del asunto; pero no los quiso. Entonces le prometí que corregiríamos el daño de algún modo. No se conformó.

- ¿De quién se trataba?

- Es gente que no conozco.

- No tienes pues por qué apurarte, Fulgor. Esa gente no existe.

(Rulfo 2007, 123)

"Whatever you say, don Pedro; but that woman who came here yesterday, weeping and accusing your son [Miguel] of killing her husband, was not to be consoled. I know how to judge grief, don Pedro, and that woman was carrying a heavy load. I offered her a hundred and fifty bushels of maize to overlook the matter, but she wouldn't take it. Then I promised we'd make things right somehow. She still wasn't satisfied."

"What was it all about?"

"I don't know the people involved."

"There's nothing to worry about, Fulgor. Those people don't really count.«

(Rulfo 1994, 65)

¿Qué quieres que haga contigo, Dorotea? Júzgate tú misma. Ve si tú puedes perdonarte.

- Yo no, padre. Pero usted sí puede. Por eso vengo a verlo.

- ¿Cuántas veces viniste aqui a pedirme que te mandara al Cielo cuando murieras? ¿Querías ver si allá encontrabas a tu hijo, no, Dorotea? Pues bien, no podrás ir ya más al Cielo. Pero que Dios te perdone.

(Rulfo 2007, 132)

${ }^{36}$ See Rulfo 2007, 101, 102, 104, 106, 108, 116, 118 and Rulfo 1994, 41, 42, 44, 46, 48, 56, 58.

37 See Rulfo 2007, 94, 101, 102 and Rulfo 1994, 33, 41. See also Rulfo 1985, 2-3; my translation: »I have nothing to say against my critics. It was difficult to accept a novel which presented itself, with apparent realism, as the story of a cacique, whereas in reality it is the story of a village: a dead town where everybody is dead. Including the narrator. In its streets and its fields only tortured souls wander, and their echoes carry indefinitely through time and space."

${ }^{38}$ See Rulfo 2007 , 117, 118, 119 and Rulfo 1994, 58, 59. Los murmullos was also the first title Rulfo chose for the manuscript (see Rulfo 1985, 3). 
"What do you think I should do with you, Dorotea? You be the judge. Can you pardon what you've done?"

"I can't, padre. But you can. That's why I'm here."

"How many times have you come to ask me to send you to Heaven when you die? You hoped to find your son there, didn't you, Dorotea? Well, you won't go to Heaven now. May God forgive you."

(Rulfo 1994, 74)

\section{Conclusion}

In my book on the problem of the narrator in fictional narrative, I evaluated the different narrative theories from the point of view of their theoretical coherency (internal coherency and coherency with the linguistic or philosophical theories to which they make reference). In this article, however, which relies on some of the demonstrations in my book, I have tried to evaluate them from the point of view of their correspondence with the facts they aim to describe and from the point of view of their consequences for interpretation. I believe I have proven the superiority of non-communicational or poetic theories of fictional narrative over communicational theories of narrative in the case of the description and the interpretation of Pedro Páramo.

To conclude, I could not put it better than Nicolas Ruwet, in his polemic with Genette on the subject of Jakobson's theory of poetics: »If we wish to evaluate these arguments, determine their potential limits, add content to anything which is still undetermined [...], we must first take them seriously, clarify them, and multiply the analysis of poems of the greatest possible variety." (Ruwet 1980,217) The same is true for non-communicational or poetic theories of fictional narrative: we must firstly take them seriously, which is far from being the case in classical and postclassical narratologies; we then need to clarify their arguments and at times reformulate them with greater precision, or using more contemporary vocabulary; lastly we must multiply analyses and interpretations of novels or short stories of the greatest possible variety, before we can judge the extent of their generality.

Sylvie Patron

U.F.R. Lettres, Art, Cinéma Université Paris Diderot - Paris 7

Translated by Susan Nicholls. 


\section{References}

Anderson, Danny J., The Ghosts of Comala. Haunted Meaning in Pedro Páramo. An Introduction to Juan Rulfo's Pedro Páramo [2003], University of Texas Press (2007), www.utexas. edu/utpress/excerpts/rulped-intro.html (08.12.2010).

Aronne-Amestoy, Lida, Utopía, paraíso e historia. Inscripción del mito en García Márquez, Rulfo y Cortázar, Amsterdam/Philadelphia 1986.

Banfield, Ann, The Formal Coherence of Represented Speech and Thought, PTL: Journal for Descriptive Poetics and Theory of Literature 3 (1978), 289-314.

-, Pour être l'avocat du diable de Flaubert, Langue Française 44 (1979), 19-26.

-, Unspeakable Sentences. Narration and Representation in the Language of Fiction, London 1982.

-, Linguistic Competence and Literary Theory, in: John Fisher (ed.), Essays on Aesthetics. Perspectives on the Work of Monroe C. Beardsley, Philadelphia 1983, 201-234.

-, Literary Pragmatics [1992], in: William Bright (ed.), The International Encyclopedia of Linguistics, vol. 2, New York/Oxford 2003, 353-358.

Benítez, Fernando, Conversaciones con Juan Rulfo [1980], in: Campbell 2003, 541-550.

Benveniste, Émile, The Correlations of Tense in the French Verb [1959], in:É. B., Problems in General Linguistics, vol. 1, transl. by Mary E. Meek, Coral Gables 1971, 205-215.

Blanco Aguinaga, Carlos, Realidad y estilo en Juan Rulfo [1955], in: Campbell 2003, 19-43.

Bradu, Fabienne, Échos de Páramo. Lecture de Pedro Páramo de Juan Rulfo [1989], transl. by Sylviane Descotte, Bruxelles 1995.

Campbell, Federico (ed.), La ficción de la memoria. Juan Rulfo ante la crítica, Mexico 2003.

Carreño, Alejandro, Los narradores de Pedro Páramo [1997], UNIACC eCampus (2004), http://ecampus.uniacc.cl/Textos/cultura/careno/acareno3.htm (08.12.2010).

De Toro, Alfonso, Los laberintos del tiempo. Temporalidad y narración como estratégia textual y lectoral en la novela contemporánea (G. García Márquez, M. Vargas Llosa, J. Rulfo, A. RobbeGrillet), Frankfurt a. M. 1992.

Doležel, Lubomír, Heterocosmica. Fiction and Possible Worlds, Baltimore/London 1998.

Espinosa-Jácome, José T., La focalización inconsciente en "Pedro Páramo", Madrid 1996.

Frenk, Mariana, Pedro Páramo [1959], in: Campbell 2003, 44-54.

Galbraith, Mary, Deictic Shift Theory and the Poetics of Involvement in Narrative, in: Judith F. Duchan/Gail A. Bruder/Lynne E. Hewitt (ed.), Deixis in Narrative. A Cognitive Science Perspective, Hillsdale 1995, 19-59.

Genette, Gérard, Narrative Discourse. An Essay in Method [1972], transl. by Jane E. Levin, Ithaca/New York 1980.

González Boixo, José Carlos, Claves narrativas de Juan Rulfo, León 1980.

-, Introducción [1983], in: Juan Rulfo, Pedro Páramo, Madrid 2007, 9-52.

Hamburger, Käte, The Logic of Literature [1957/21968], transl. by Marilynn J. Rose, Bloomington/Indianapolis 1993.

Jiménez de Báez, Yvette, Juan Rulfo, del páramo a la esperanza. Una lectura crítica de su obra, Mexico 1990.

Kayser, Wolfgang, Interpretación y análisis de la obra literaria [1948], transl. by María D. Mouto/Valentín García Yebra, Madrid 1970.

-, Entstehung und Krise des modernen Romans, Stuttgart 1955. 
Kuroda, Shigeyuki (S.-Y.), Where Epistemology, Style and Grammar Meet. A Case Study from the Japanese, in: Stephen R. Anderson/Paul Kiparsky (ed.), A Festschrift for Morris Halle, New York 1973, 377-391.

-, Reflections on the Foundations of Narrative Theory - from a Linguistic Point of View [1975], in: Teun A. van Djik (ed.), Pragmatics of Language and Literature, Amsterdam/ New York 1976, 107-140.

-, Some Thoughts on the Foundations of the Theory of Language Use, Linguistics and Philosophy 3:1 (1979), 1-17.

-, The Reformulated Theory of Speech Acts. Towards a Theory of Language Use, Versus 26-27 (1980), 67-79.

Leal, Luis, La estructura de Pedro Páramo [1964], in: Recopilación de textos sobre Juan Rulfo, Havana 1995, 96-105.

Llarena, Alicia, Realismo Mágico y Lo Real Maravilloso: una cuestión de verosimilitud (Espacio y actitud en cuatro novellas latinoamericanas), Gaithersburg 1997.

Luraschi, Ilse Adriana, Narradores en la obra de Juan Rulfo. Estudio de sus funciones y efectos, Cuadernos Hispanoamericanos 308 (1976) 5-29.

Martínez Bonati, Félix, La estructura de la obra literaria [1960], Barcelona ${ }^{2} 1972$.

-, Fictive Discourse and the Structures of Literature: A Phenomenological Approach [1960], transl. by Philip W. Silver, Ithaca/London 1981.

Ortega, José, Estructura temporal y temporalidad en Pedro Páramo, in: J. O., Letras Hispanoamericanas de nuestro tiempo, Madrid 1976, 9-24.

Ortega Galindo, Luis, Expresión y sentido de Juan Rulfo, Madrid 1984.

Palaisi-Robert, Marie-Agnès, Juan Rulfo: l'incertain, Paris 2003.

Patron, Sylvie, Le Narrateur: Introduction à la théorie narrative, Paris 2009.

Rodríguez Monegal, Emir, Relectura de Pedro Páramo [1974], in: Campbell 2003, 121-135.

Rulfo, Juan, Pedro Páramo, Mexico 1955.

-, Pedro Páramo [1955], ed. by José Carlos/González Boixo, Madrid 2007.

-, Pedro Páramo [1955], transl. by Lysander Kemp, New York 1959.

-, Pedro Páramo [1955], transl. by Margaret Sayers Peden, New York 1994.

-, Pedro Páramo, treinta años después, Proyekto Patrimonio, El salón de lecturaen español de internet (1985), www.letras.s5.com/rulfo160202.htm (08.12.2010).

Ruwet, Nicolas, Malherbe: Hermogène ou Cratyle?, Poétique 42 (1980), 195-224.

Searle, John R., The Logic Status of Fictional Discourse [1975], in: J. R. S., Expression and Meaning, Cambridge 1979, 58-75.

Stanzel, Franz K., Narrative Situations in the Novel: Tom Jones, Moby Dick, The Ambassadors, Ulysses [1955], transl. by James Pusack, Bloomington/London 1971.

-, A Theory of Narrative [1979], transl. by Charlotte Goedsche, Cambridge 1984.

Tacca, Oscar, Las voces de la novela, Madrid 1973.

Zepeda, Jorge, La recepción inicial de Pedro Páramo (1955-1963), Mexico 2005. 